\title{
COMMENT
}

\section{Do deep-sea nematodes show a positive latitudinal gradient of species diversity? The potential role of depth}

\author{
Michael A. Rex*, Carol T. Stuart, Ron J. Etter \\ Department of Biology, University of Massachusetts Boston, 100 Morrissey Blvd., Boston, Massachusetts 02125, USA
}

Latitudinal species diversity gradients (LSDGs) are among the most conspicuous biogeographic patterns on Earth. Poleward declines in the number of species are known for terrestrial, aquatic, coastal marine and pelagic marine biotas, but the explanation for these patterns remains a challenge for theoretical ecology (Gaston 2000). Recently, LSDGs were reported for several macrofaunal taxa collected from bathyal depths in the deep sea of the Atlantic (Poore \& Wilson 1993, Rex et al. 1993, 1997, 2000, Stuart \& Rex 1994, Wilson 1998). Modern deep-sea foraminiferans also show LSDGs in the Atlantic (Culver \& Buzas 2000). Foraminiferan assemblages from deep seabed cores reveal the historical development of LSDGs during global cooling of the Cenozoic (Thomas \& Gooday 1996). It has been stressed repeatedly that knowledge of these large-scale biogeographic patterns in the deep sea is very new, and is based on limited sample coverage and few taxa (e.g. Rex et al. 1997, 2000). Yet the patterns, if they prove to be more widespread, are potentially important for understanding the underlying causes of global LSDGs because the deep sea is such a distinctive environment.

A recent paper by Lambshead et al. (2000) reported that deep-sea nematode diversity increases from $13^{\circ}$ to $56^{\circ}$ in the North Atlantic. Here we show that when their analysis is corrected for differences in depth of sampling a clear latitudinal pattern is not apparent.

The data analyzed by Lambshead et al. (2000) represent 6 sites in the North Atlantic and 1 site in the Caribbean Sea. The sites comprise a heterogeneous set of habitat types including those that have experienced massive disturbance from turbidites (Madeira Abyssal Plain and the Venezuela Basin), a region (HEBBLE) that is chronically disturbed by benthic storms, and a deep-sea trench off Puerto Rico. Nematode diversity was estimated from a variable number (2 to 9) of small quantitative cores that varied in size

\footnotetext{
*E-mail: michael.rex@umb.edu
}

( $\leq 77 \mathrm{~cm}^{2}$, see e.g. Tietjen 1984, 1989, Thistle \& Sherman 1985, Lambshead et al. 1994). The number of species was used as the primary dependent variable. Strictly speaking, the number of species is highly dependent on sampling effort and should not be used for intersite comparisons unless it is demonstrated that the faunas are well characterized - that the species accumulation curves have become asymptotic (Etter \& Mullineaux 2000). However, to be perfectly fair, as Rex et al. $(1997,2000)$ point out, current efforts to document the large-scale structure of deep-sea communities all face problems of sampling disparity and considerable uncertainty about environmental control. Lambshead et al. used the best available data on nematodes to explore ocean-wide patterns.

To test for a latitudinal pattern of diversity, Lambshead et al. performed a multiple regression with the number of species as the dependent variable, and the number of individuals and latitude as independent variables. The number of individuals was used to remove the effects of differences in sampling intensity (number of samples and sample size) among sites. Number of individuals explained most of the variance in species number (82\%), and latitude accounted for a small (8\%) but significant part of the residual variance, and the relationship was positive. From this result, the authors concluded that nematodes show a poleward increase in diversity.

However, detecting a latitudinal component of diversity in the deep sea also requires controlling for depth, either by using data from a particular depth zone (Culver \& Buzas 2000, Rex et al. 2000), or by statistically removing the effect of depth (Etter \& Grassle 1992, Rex et al. 1993). Species diversity varies strongly with depth and diversity-depth patterns vary geographically from basin to basin in the Atlantic (Rex et al. 1997). It is necessary to hold depth constant to show that apparent latitudinal variation in diversity is not merely a spurious consequence of differences in sampling depth among regions. 
The samples used by Lambshead et al. range in depth from 545 to $8380 \mathrm{~m}$, and the number of species varies by 3 -fold. It is immaterial that, as the authors noted, nematode diversity is uncorrelated with depth in their dataset. This might be expected because no individual site has sufficient data to test statistically for a diversity-depth relationship, and the sites represent very different environments and ranges of sampling depths. Depth can still play a significant role in the multiple regression (cf., e.g., Stuart \& Rex 1994), and should be included in such analyses a priori to remove its potentially confounding effects. When depth is included as a simple linear independent variable in a multiple regression, the number of individuals $(t=$ 9.912, $\mathrm{p}<0.001)$ and depth $(t=2.644, \mathrm{p}=0.021)$ enter the equation as significant variables, together accounting for $93 \%$ of the variance in diversity. Latitude becomes insignificant $(t=1.116, \mathrm{p}=0.286)$. When depth squared is added as an independent variable to correct for possible curvilinearity, latitude remains marginally insignificant at the $5 \%$ level $(t=2.195, \mathrm{p}=$ 0.051). We suggest that a conservative interpretation would be that, once sample size and the effects of depth are removed, species diversity does not show a clear latitudinal pattern by using this dataset.

A fundamental limitation of the data reported by Lambshead et al. is that when sampling effects are held constant, less than $20 \%$ of the variance in number of species remains to be attributed to geographic variables. With so few samples and colinearity among independent variables, it is difficult to make any statistically compelling argument about geographic variation in species diversity. However, the result of adding depth to the analysis should not be construed to mean that deep-sea nematodes do not actually have largescale geographic trends in diversity. It is just difficult to discern patterns using the currently available data. If nematodes do not have a latitudinal gradient in diversity, or have a positive gradient, this could be a very interesting result. Nematodes may respond to the deep-sea environment in a way that is fundamentally different from other organisms.

Studies of large-scale biogeography in the deep sea are in an early and inductive phase. The vast amount of archived and new faunal material collected from the deep ocean presents an opportunity to expand our knowledge of global LSDGs and other large-scale patterns. Documenting these patterns requires a large number of samples and broad geographic coverage in order to statistically detect meaningful geographic signals, because diversity shows variation at all spatial scales in this ecosystem (Grassle \& Maciolek 1992, Rex et al. 2000). In deep-sea communities, it is also important that such studies be controlled as well as possible for habitat type, other geographic variables such as depth, taxonomy, sampling methods and analytical approaches. Experience in deep-sea ecology during the past several decades shows that a variety of patterns may emerge in different taxa depending on their ecology and evolutionary history, and the spatial and temporal scales examined.

\section{LITERATURE CITED}

Culver SJ, Buzas MA (2000) Global latitudinal species diversity gradient in deep-sea benthic foraminifera. Deep-Sea Res I 47:259-275

Etter RJ, Grassle JF (1992) Patterns of species diversity in the deep sea as a function of sediment particle size diversity. Nature 360:576-578

Etter RJ, Mullineaux L (in press) Deep-sea communities. In: Bertness MD, Gaines SD, Hay ME (eds) Marine community ecology. Sinauer Associates, Sunderland, MA

Gaston KJ (2000) Global patterns in biodiversity. Nature 405: $220-227$

Grassle JF, Maciolek NJ (1992) Deep-sea species richness: regional and local diversity estimates from quantitative bottom samples. Am Nat 139:313-341

Lambshead PJD, Elce BJ, Thistle D, Eckman JE, Barnett PRO (1994) A comparison of the biodiversity of deep-sea marine nematodes from three stations in the Rockall Trough, Northeast Atlantic, and one station in the San Diego Trough, Northeast Pacific. Biodivers Lett 2:95-107

Lambshead PJD, Tietjen J, Ferrero T, Jensen P (2000) Latitudinal diversity gradients in the deep sea with special reference to North Atlantic nematodes. Mar Ecol Prog Ser 194:159-167

Poore GCB, Wilson GDF (1993) Marine species richness. Nature 361:597-598

Rex MA, Stuart CT, Hessler RR, Allen JA, Sanders HL, Wilson GDF (1993) Global-scale latitudinal patterns of species diversity in the deep-sea benthos. Nature 365:636-639

Rex MA, Etter RJ, Stuart CT (1997) Large-scale patterns of species diversity in the deep-sea benthos. In: Ormond RFG, Gage JD, Angel MV (eds) Marine biodiversity. Cambridge University Press, Cambridge, p 94-121

Rex MA, Stuart CT, Coyne G (2000) Latitudinal gradients of species richness in the deep-sea benthos of the North Atlantic. Proc Natl Acad Sci USA 97:4082-4085

Stuart CT, Rex MA (1994) The relationship between development pattern and species diversity in deep-sea prosobranch snails. In: Young CM, Eckelbarger KJ (eds) Reproduction, larval biology and recruitment in the deep-sea benthos. Columbia University Press, New York, p 119-136

Thistle D, Sherman KM (1985) The nematode fauna of a deepsea site exposed to strong near-bottom currents. Deep-Sea Res 32:1077-1088

Thomas E, Gooday AJ (1996) Cenozoic deep-sea benthic foraminifers: tracers for changes in oceanic productivity? Geology 24:355-358

Tietjen JH (1984) Distribution and species diversity of deepsea nematodes in the Venezuela Basin. Deep-Sea Res 31: 119-132

Tietjen JH (1989) Ecology of deep-sea nematodes from the Puerto Rico Trench area and Hatteras Abyssal Plain. Deep-Sea Res 36:1579-1594

Wilson GDF (1998) Historical influences on deep-sea isopod diversity in the Atlantic Ocean. Deep-Sea Res II 45: 279-301 